\title{
The Relationship between Waldorf Pedagogy and Information and Communication Technologies in Hungary
}

\author{
Mátyás Turós* \\ Received: October 20, 2020; received in revised form: February 7, 2021; \\ accepted: February 9, 2021
}

\begin{abstract}
:
Introduction: The number of two-to three-year-old children using mobile phones was 10\% in 2013 compared to $40 \%$ in 2017 (Konok, Bunford, \& Miklósi, 2020). Several theoretical and empirical studies deal with the didactics of using modern technology in the classroom. Most studies highlight the neutral (Zsolnai, 2017) or positive impact of using ICT in the classroom. Only a few address the negative effects of digitally enhanced learning (Dávila, Casabayó, \& Rayburn, 2018; Livingstone, 2012; Lorenzo $\&$ Trujillo, 2018). State education has continually tried to integrate modern technology with education, but there are also examples of institutional restrictions on its use and even a total ban can also be found.

Purpose: This study provides an overview of the pedagogical and epistemological reasons why Waldorf pedagogy and Waldorf Steiner schools take a critical approach to the use of information and communication technologies (ICT) and to "screens" in general, together with mapping out the current state of Waldorf schools in Hungary.

Methods: In the present study, we applied source analysis as a traditional research method in the philosophy of education.

Conclusions: The findings show that the institutional use of information and communication technologies entirely contradicts the basis, tasks and spirit of Waldorf pedagogy. If we look at the epistemology and anthroposophical anthropology of Waldorf pedagogy, we can see that the autonomy of a Waldorf teacher is not limitless, and so a continuous practical and theoretical responsibility of the Waldorf movement and Waldorf teachers is to establish and uphold coherence between the practices of every Waldorf institution and Waldorf pedagogy.
\end{abstract}

Key words: epistemology, ICT, Waldorf pedagogy, ICT negative impact on pedagogy, Rudolf Steiner.

\footnotetext{
* Mátyás Turós, Eszterházy Károly University of Applied Sciences, Eger, Hungary; turos.matyas@uni-eszterhazy.hu
} 


\section{Acta Educationis Generalis \\ Volume 12, 2022, Issue 1}

\section{Introduction: Waldorf schools in Hungary at present}

The question should not be: What does a human being need to know and be able to do for the social order that now exists?, but rather: What capacities are latent in this human being, and what lies within that can be developed? (Steiner, 1985, p. 72)

Globally, Waldorf Kindergartens and Schools are partially state funded. In Hungary, this guarantees that, by law (Section 31 (2) and Section 9 (8) of Act on National Public Education), a Waldorf institution, just like any other independent school, can embrace an ideology, and consequently, the school can base its admission policy around this. Waldorf schools are not required by law to admit everyone, and in this respect, they are not an institution that offers public service. They are also more self-reliant than state-funded institutions with regards to management and governance. According to this position and their pedagogical theory, these institutions check not only a child's cognitive skills during the admission procedure (e.g. learning assessments) but all elements of the individual's complexity in equal measures, including affective, cognitive, motor and social skills as well as the parenting style of the family and the predictable level of cooperation between the family and the pedagogy of the school. They also aim to continue to shape these factors later on. Such schools allow for the transition between their own educational structure and mainstream schools at any time during the learning process. In Hungary, these schools are defined as public primary and secondary schools of Art, all following the Waldorf Curriculum accredited by law 13 years ago. The first twelve years are divided into Lower, Middle and Upper schools, and which each lasting for four years, are followed by another year wholly dedicated to preparing for the Matura, or State Examination.

Steiner Waldorf education is the most widespread progressive educational movement in the world. There are about 3000 Waldorf Steiner Schools and Kindergartens around the globe. According to a 2019 survey, 2154 are located in Europe (https://bit.ly/2JFxyBe). Hungary is always the third or fourth in the list of countries with the most Waldorf schools per capita every year, and other progressive education movements (value mediation and skills development pedagogy, Montessori, Dalton, Freinet, Jean-Plan, Rogers, independent) comprise about half the number of Waldorf schools altogether. This success is the result of the originality of the Waldorf school method ${ }^{1}$, its outstanding achievements in certain areas (Sobo, 2015), its considerable and growing reputation, its own Teacher Training Courses ${ }^{2}$, its effective protection of

\footnotetext{
${ }^{1}$ Certain conceptions influence each other, for example Maria Montessori's definition of „,cosmic education” Frierson (2014).

${ }^{2}$ Professor Emerita Zsuzsa Mesterházi, who is the ex-leader of the Doctoral School of Education at the Faculty of Special Educational Needs at ELTE, founded the Faculty of Waldorf Teacher Training Programme in Hungary in 1990, and directed it for a long time at Bárczi Gusztáv Faculty of Special Educational Needs. Tamás Vekerdy who was one of the teachers and founders of the Solymár Waldorf Teacher Training
} 


\section{Acta Educationis Generalis \\ Volume 12, 2022, Issue 1}

interests and educational services, and of its everyday contributions made by its teachers and parents. In 2019 the number of children attending the one hundred Waldorf Schools or Kindergartens in Hungary was 8500, and more than 9000 in 2020, comprising $0.6 \%$ of the total number of children, 1469000 , participating in education in Hungary. In recent years, there has been such a constantly increasing initiative to found Waldorf schools in the country that these schools continually lack Waldorf trained teachers, but the rate of oversubscription is high every year. This increase in numbers and popularity is the result of not just the pedagogy itself, but of a loss of trust in mainstream education, caused by the increasing political attacks on state education since 2010 (Kopasz \& Boda, 2018). Hungarian Waldorf Steiner Schools thus have to face several challenges:

1. Most parents first meet Waldorf pedagogy during their children's school years, and this is the period when they start to appreciate its principles which demands continual conversation between the participants and a high level of professional and communicational skills from the teachers.

2. The growing number of schools does not necessarily go hand in hand with a growing number of trained teachers ${ }^{3}$ and the legitimacy of a Waldorf Teacher Certificate not based on the traditional teacher training programme can be limited, because teachers who only hold this qualification might acquire a one-sided pedagogical-professional knowledge and approach.

3. Schools have to face a more and more restricted legal system, tightening regulations, and increasing difficulties in the protection of interests through one body.

4. Waldorf pedagogy and Constructivist pedagogy are blurred: alternative, eclectic schools are founded as Waldorf schools, or Waldorf schools are exclusively interpreted as independent, innovative and alternative school models (Steiner, 2004, pp. 103-104).

5. The rhetoric of sharp and generalised criticism against mainstream education as a self-defining element of the social status and role of Waldorf schools.

6. Pedagogical and epistemological subjectivism is attributed to Waldorf pedagogy (and such practices are promoted) in spite of being totally contradictory to its groundings (Steiner, 1928, pp. 38-84).

7. There is a debate around the question on the use of information and communication technologies in the classroom, often kept within the

\footnotetext{
Programme, spent his life popularising alternative schools and the Waldorf pedagogy. Zoltán Döbröntei founded Napút Art Academy in 2007, which organises painting courses based on anthroposophy. He also led a community working, learning and creating together for 10 years, apart from his performing, lecturing and publishing career. Waldorf schools include some specific subjects, such as Bothmer gym and Eurythmy. László Baditz, Ildikó Szántó and László Varga-Szemes founded the Bothmer Movement Training in 1995. Mária Scheily and Clemens Schleuning started Eurythmy Teacher Training in 1992.

${ }^{3} 47 \%$ of Waldorf teachers in Hungary have a Waldorf Teacher Training Certificate and $51 \%$ in international research studies. Schools are trying to compensate for, or overcome, these shortcomings by sending teachers to workshops or on postgraduate courses.
} 


\section{Acta Educationis Generalis \\ Volume 12, 2022, Issue 1}

conceptual framework of "dogmatism vs. innovation" in the Waldorf movement.

\section{Rudolf Steiner's anthroposophy}

At the turn of the nineteenth and twentieth century, there had been a growing demand for a human science suitable for establishing principles equal to those in the natural sciences, and for an epistemology to serve as the basis for an exact distinction between the human and natural sciences, which had been opposed to each other since the time of David Hume and John Stuart Mill. Human science, having surpassed descriptive psychology, was standing on the groundwork of hermeneutics and anti-psychology in the 1890s, when human sciences were aiming to examine and reveal the objectified spirit after the discussion of the individual in the earlier times, stating also that life is not, or not entirely, a psychological reality and that fully grasping its purpose should be sought outside individual life. The late Wilhelm Dilthey wished to present the basis and legitimacy of the human science conveying a universal knowledge generated from direct experience that is able to overcome the subjectivity of the experience and to provide purpose of life; but he could not identify with subordinating the human being into massive constructions, which seemed contradictory to the image of a free, irrational individual being:

It seems impossible to me that there could be a metaphysics which would attempt to conclusively express the world's coherency by using an interconnection of concepts (...) I merely adhere to the movement which, since the second half of the eighteenth century, has continued to negate metaphysics, as understood in the sense given above - Letter from Wilhelm Dilthey to Edmund Husserl (1911, Husserl, 1981, p. 203).

When researching spiritual truths, the logos, body language, productions and patterns of behaviour are to be understood instead of the processes of intelligence, feelings and the will in the individual:

The subjects of all statements in these studies are socially interrelated, individual selves. These are, first of all, single persons. Gestures, words, and acts are their manifestations. The problem of the human studies is to relive these selves and to grasp them in thought (1907, Dilthey, 1969, p. 2).

While modern sciences were being established and improved, there was less possibility for specialised scientists to examine their questions from a broader, philosophical perspective. Approaching a problem from an overall scientific and epistemological view has been highly valued since the turn of the century. Thinking about adopting the methodology of natural sciences for human sciences was considered alongside the tendencies and trends of the era (Durkheim, 1982; Neurath, 1936), as well as Rudolf Steiner's epistemological conceptions (Steiner, 1995, 1997), who was well acquainted with scientific ideas and his fellow thinkers (Steiner, 1981) and was then considering working for an academy at the beginning of his career: 


\section{Acta Educationis Generalis \\ Volume 12, 2022, Issue 1}

Thus, our rule implies no metaphysical conception, no speculation about the innermost depth of being. What it demands is that the sociologist should assume the state of mind of physicists, chemists and physiologists when they venture into an as yet unexplored area of their scientific field (1893, Durkheim, 1982, p. 37). It is the intent of spiritual science to free the methods and attitudes of scientific research from their particular application to the relationships and processes of sensory facts while preserving their way of thinking and other attributes (1910, Steiner, 1997, p. 14).

Some results of introspective observation following the methods of Natural Science (Steiner, 1967).

The realms of life are many. For each, specific sciences develop. But life itself is a unity, and the more the sciences busily immerse themselves in separate realms, the farther they move away from seeing the living wholeness of the world. There must be a kind of knowing that seeks, in the separate sciences, the elements that lead human beings back to full life again. A scientific specialist wants to become aware of the world and how it works through his or her insights. In this book, the goal is philosophical: science itself is to become organically alive. The separate sciences are preludes to the science attempted here (Steiner, 1995, $p$. 256).

The purpose of this new encyclopaedia, which is only an addition to other encyclopaedias, is to give all men a common starting-point of knowledge, to make one united science, forming a connection between the special sciences and putting together the work of different nations, to give simple and clear accounts of everything as a solid base for our thoughts and our acts, and to make us fully conscious of conditions in which we are living (Neurath, 1936, p. 111).

In The Philosophy of Freedom, Rudolf Steiner outlined a way to knowledge which placed thinking at its centre (Dahlin, 2009). Steiner expanded Goethe's methodology, which rejects teleology and views evolution as a metamorphosis (Park \& Song, 2018) and renders thinking and fantasy to observation, with the hierarchy of systems theory embedded in the conceptual world of his era. $\mathrm{He}$ perceived all phenomena as creature-like spirits, from the natural world to human beings, and further up to the planets and stars. He declared that he examined the laws of not just the life hierarchies below the life spheres of the mechanical, observing subject; but the laws of the life hierarchies above the life spheres of the live, observing subject. Steiner thought that all entities, from the natural world to humans, and to the stellar system, were objective spirits falling into their appropriate hierarchical categories.

Consequently, their level of perception, being also hierarchical, and the strength of the developing cognition, become decisive in the question of how much of the whole reality can be perceived, and furthermore, how much can be considered natural phenomena and coherence based on scientific, or casual relationships. Just like Neoplatonism and Gnosticism, Steiner correlated the supreme with the world, structured it, and placed it into the categories of phenomena. Steiner 


\section{Acta Educationis Generalis \\ Volume 12, 2022, Issue 1}

considered the development of morality, and not the development of science in the sense we would use it today, as the basis and as an absolute necessary condition for individual and social development. Steiner gave anthroposophy a scientific direction and approach in the modern sense, with extended methods, and also defined it with methodological, empirical, and straightforward experience-based characteristics (Steiner, 2003, pp. 7-31).

Steiner, as a philosopher, belonged to the tradition according to which reality can be grasped as an observation which is an interplay between thinking and perception: thinking makes an imperfect and fragmented perception indicating distinctive existences complete in the conceptual world. Observation, in Steiner's view, can be extended beyond the immediate realms of perception, because thinking which converts itself into its own object of observation can direct human cognition toward a complex and objective reality (Steiner, 1995). According to the starting point of epistemology, the human being in anthroposophy is at the same time a finite natural (perceptive) and a free spiritual (thinking) being, who as part of the latter quality does not just get acquainted with, but also, creates the world, which does not manifest itself as a closed system. As a finite natural being, a person's ability to surpass themselves basically depends not on the technological, but on their moral development (Steiner, 2011). Rudolf Steiner's anthroposophical spiritual science is relevant in intellectual history, but:

1) it does not use the language of philosophy or another discipline;

2) it was criticised in the beginning on the basis that its theories were not original (Steiner, 2006, pp. 199-213):

Question to Steiner: I got hold of a brochure written by a certain Herr Hauer. I suppose you read it and you know about it. This man states that you do not say anything new, everything that can be found in the doctrines of anthroposophy is already heard of, everybody knows it. Answer by Steiner: Naturally, ancient wisdom can be found, made available, one part of it here and another there. And on this basis, Herr Hauer read parts here and others there, and gained knowledge about it - but this is not how I have acquired my knowledge about it and he draws the consequence: 'Steiner only states what we can find already written by other thinkers. 'This how we become at the mercy of this kind of people. When Herr Hauer should give an opinion on my doctrines, he goes on saying: 'But Steiner says nothing new!' If I were about to write a book on Geometry, I should explain Pythagorean theorem; although Pythagoras discovered it in 600 BC. If I were to develop new theories, I should still include this theorem, as well. You cannot reproach somebody for mentioning something that has already been known when people have forgotten about it at the time. This is how it happens that, what spiritual science states today, but in a different way, because it is indeed formulated differently, can be found in Gnostic writings, who were the writers of an earlier age. Gnostics wrote about ancient 


\section{Acta Educationis Generalis \\ Volume 12, 2022, Issue 1}

wisdom and overtook it as it was, but their knowledge was not permeated with science gained by thinking, like in anthroposophy.

3) its thinkers cannot come up with a methodology valued in a scientific sense or with research study results, with a few, exceptional cases (Hauschka, 2002a, 2002b; Páleš, 2009).

It remained on the level of marginality and exclusivity and was rarely canonical in the academic circles. Only a few empirical studies deal with anthroposophy and science, and the question of the relationship between anthroposophy and Waldorf pedagogy (Leber, 2016; Oberski, 2011; Randoll \& Peters, 2015) and in the past two decades, scarcely any dissertations can be found on the topic, anywhere in the world (Lejon, 1997; Mansikka, 2007; Ramirez, 2006). Despite this, Waldorf pedagogy has become widespread around the world.

Significant elements of the anthroposophical spiritual science based on Steiner's epistemological groundings and elements of Waldorf pedagogy based on this science both have roots in earlier times ${ }^{4}$, however, its phenomenological (in Rudolf Steiner's terminology symptomological) statements about the human being, nature, science, pedagogy, arts are original, and they are unfolding a human-scientific approach. An example of this is how it explains natural phenomena as moral, allegorical entities, as a kind of natural scientific hermeneutics (Steiner, 2013):

Well, the way in which people construct machines, for instance, varies greatly according to the nature of the machine in question; at present machines are still imperfect and primitive, but everything tends towards the gradual development of a kind of machine that depends on oscillations, in which oscillation, vibration,

\footnotetext{
${ }^{4}$ For example, illustrating the hierarchies of the beings can be detected before Greek philosophy, e.g. the different registers on the Uruk Vase, and later, in Plato's analogy of the divided line (VI/509d-511e.) This was then followed by the long and complete periods of Western thought reaching to the Middle Ages, such as Dionysius the Areopagite's Ecclesiastical Hierarchy, Raymundus Lullus's Theory of Elements (Lullus pictured the staircases in Liber de ascensum as lapis, flora, planta, brutu, homo, celum, angeli, Deus - his ladder of beings), further examples: Bouelles (1512), Bonnet (1745); Hermann (1783); Lamarc (1809); Darwin (1859); Haeckel (1874); Reid (1882); Sparks (1932); Lewis (1992); Blackmore and Troscianko (2003) (as cited in Lovejoy, 2009) followed. Some of these evolution theories (Darwin, Haeckel, Lewis) had humans at the top, others (Llull, Bouelles, Reid) place spiritual beings above humans (Bouelles has got nine hierarchical levels above humans starting from the angels and rising up to the seraphins). Systems Theory, which was born at the turn of the century in the middle of Europe (with Alfred Schütz a social phenomenologist and with Ludwig von Bertalanffy, the founder of the general systems theory, both living in Vienna), left the allegories of Ancient Times and the Middle Ages behind, exchanged ontological models for epistemological ones, more appropriate for the modern mind with Western scientific rhetoric, and structured the world hierarchically from static formations to plants, animals, humans, to society and to higher levels impossible to comprehend Boulding (1956). Although this taxonomy mentions nothing about the validity of Steiner's theories, it is unlikely that Rudolf Steiner, with a residency in Vienna, would not have known about the historical-cultural backgrounds. Numerous other examples could be taken from Rudolf Steiner's works as examples for this; the life hierarchical theory is just one - that existed before his time. For example, the three- and the fourfold nature correspond with three and four spheres in Origen of Alexandria's and John Cassian's biblical hermeneutics. The definitions and the methodological use of thinking, feeling and willing can be traced back to the ancient Greek philosophers, to Immanuel Kant and Johann Friedrich Herbart. Education being independent from the state, and the freedom to research and to teach were both first discussed by Wilhelm von Humboldt; harmonising the teaching material with the "cultural epochs" theory was first mentioned by Tuiskon Ziller.
} 


\section{Acta Educationis Generalis \\ Volume 12, 2022, Issue 1}

and sequential motion produce the machine's effect. (...) That is the terrible law of oscillations sounding in unison that would be fulfilled if the alluring call of the cow so seduces the Orient that the East would then be able to wholly penetrate the unspiritual, purely mechanistic civilization of the West and Centre. It would then become possible to create on the earth a mechanistic system of the universe. Everything connected with the activities of the air, of the environment, and everything connected with the activities of the stars, would be exterminated from human civilization. What human beings experience, for instance, through the cycle of the year, what they experience through living together with the sprouting, budding life of spring, with the fading, dying life of autumn - all this would lose its significance for them. Human civilization would resound with the clattering and rattling of oscillating machines and with the echo of this clattering and rattling, which would stream down to earth from the cosmos as a reaction to this mechanization of earth. If you observe a part of what is active at the present time, you will say yourselves: A part of our present-day civilization is actually on the way to having this terrible element of decline and fall as its goal (Steiner, 2013, pp. 30-31).

On these grounds, technology using electricity poses dangers to cultural, and social development, and to the evolution of consciousness (Steiner, 2000), which is relevant in a pedagogical sense. It is of importance how Steiner views electricity and modern technology using electricity in a methodological relation to Goethe's phenomenological studies of humanity and nature (Okumoto, 2019, p. 84; Steiner, 1928). Since this approach has been present in Waldorf pedagogy and in Waldorf schools, backed up by developmental psychological and institutional educational perspectives.

\section{Information and communication technology from the perspective of Waldorf pedagogy}

\subsection{A developmental psychological view}

Rudolf Steiner stated that concepts and concept acquisition have a pictorial (spiritual) origin, where the concept (as an abstraction) is fading away, the picture is bearing "the powers of germination", whereas pure intellect leads to the different forms of ossification (Steiner, 1961). Based on his anthropology and on psychology, in his pedagogical lectures, Steiner says that the main point of the teaching-learning process is to transmit pictures, especially, and not to expand concept acquisition with abstract definitions (Steiner, 1996). The logic of educational process in Waldorf pedagogy (second line) differs basically from the rational model (first line):

$$
\begin{array}{lll}
\text { DEFINITION (scientific) } & » \text { CONCEPT (learning) } \\
\text { MEANING (picture) MEANING (knowledge) } & \gg \text { CONCEPT (learning) } & \text { MEFINITION (artistic) }
\end{array}
$$




\section{Acta Educationis Generalis \\ Volume 12, 2022, Issue 1}

Bearing this and the literature in mind, Waldorf pedagogy is not a model focusing on the experience of acquisition but on the experience of knowledge, ideally, the "scientific" and the "artistic" overlapping each other, not just formally but contextually as well, so it is not part of the didactics to generate positive, emotionally amplified self-serving experience. As seen in the model above, the emphasis in the didactics of Waldorf pedagogy is not on building a system of abstract concepts in the learner, primarily, because the purely intellectual model leaves certain dimensions of the individual, like the instinctive-regulatory ones, untouched. The pictorial-moral representation of the world supports the young child in healthy development and not the conceptualscientific explanation, but as Waldorf pedagogy nourishes age-appropriate conceptual thinking, it cannot be considered a naturalistic pedagogical model. In summary, the basis of the educational process in Rudolf Steiner's pedagogy is the shift (improvement) in the direction of the real pictorial world depending on one's own inner and moral powers; and not encouragement to immerse oneself in the virtual image-world leading to materialisation and affecting the electrochemical processes of the nervous system. This results, partly, in educators telling stories learned by heart, pupils creating and using their own main lesson books, and completely omitting or reducing the use of digital tools.

\subsection{Educational-pedagogical perspective $e^{5}$}

The human being, says Rudolf Steiner, as a spiritual being, understands the phenomena of the world in that they place themselves (their attention) into the phenomena perceived by them and connect it with the already existing concepts of individuality in an imaginative way (Steiner, 1996, pp. 31-46).Understanding the world is possible through the signs (sensations) here as well, but from an anthroposophical point of view, the human being as a spiritual being is capable of comprehending the meaning to which the signs refer. Although:

1) computers can work with signs but not with meaning, the manipulation of data creates the impression that the computer understands what it is doing; consequently, the user, considering the machine as something surpassing their abilities in certain areas, takes it as their partner; the computer is capable of determining the rhythm of its user's life (Jin Jeong, Suh, \& Gweon, 2020; Yamada, Moshier, \& Otto, 2016);

2) the whole operation of the computer is comprehensible for its user through interfaces and peripheries. When using it, one can easily leave their innerhigher self for a practical, shallow realm where they spend their time continuously. People working on computers may feel that logical, clear steps have incomprehensible consequences, so soon one realises that to overcome these challenges one usually has to follow logically

\footnotetext{
${ }^{5}$ The above-mentioned approach and perspectives were present in the Waldorf Curriculum implemented in the second appendix of the 17/2004. (V.20.) OM decree, but they are not present in the currently effective law.
} 


\section{Acta Educationis Generalis \\ Volume 12, 2022, Issue 1}

incomprehensible conditions or has to turn to hoaxes. If this practice is enforced in the long run, a person, especially a child, experiences several delusions about the problems of the world: a) every problem can be solved, one just needs to try hard, b) problems are built up from tiny particles and are illogical, c) solving one small challenge means one can cope with a difficult task at once, everything operates perfectly;

3) languages used by computers lack all the nuances and richness of a living language which has relevant and negative consequences in a pedagogical sense; these are instructions, commands aimed at one special task (e.g. processing data), resembling the language used in the military, where these commands are not contradicted and unsophisticated.

Rudolf Steiner states that the relationship between the human being and the world is moral and individual. These attributes are entirely anti-computer. In Waldorf pedagogy learning based on the use of Information Technology poses problems:

1) it makes gaining knowledge and experiences similar to mercantilism. The status of "the educator and the learner" or "the master and apprentice" becomes similar to that of "a user and a supplier", where the educator does not, or hardly influences the learner's personal development. Moreover, the kind of knowledge that cannot be transformed into information is lost (Lankshear, Peters, \& Knobel, 2000, pp. 21-23);

2) due to the connection with the virtual world, the sense of reality becomes weaker, thinking becomes illusory and unrealistic, humans become more vulnerable, easily influenced in spite of the seemingly increasing freedom;

3) improving technology makes computers smaller in size, where the processes are carried out in a condensed space, greatly isolated from its environment, at high speed, but oppositional to the organic and slow development specific to humans and to nature, and to the world humans live in. Although it is similar to the possible characteristics of spiritual beings (e.g. speed, boundless, free creativity), humans can reach this realm by using an external tool they cannot control or comprehend, and which is rather problematic (Lorenzo \& Trujillo, 2018);

4) a source of danger is that the feedback and assessment is impersonal, free from several dimensions of humanity, so the younger the child the less helpful it is (Klimov, 2012, p. 197).

\section{Discussion}

According to the anthroposophical anthropology in Waldorf pedagogy, and to the Steiner's theory of human developmental stages, a young child's basic quality is imitation; children around puberty live in their feelings, and adolescents develop the power of own judgement stemming from the urge to be separate. One of the most essential tasks of Waldorf educators is nourishing and following a child's developmental stages with age-appropriate teaching 


\section{Acta Educationis Generalis \\ Volume 12, 2022, Issue 1}

materials. A young child identifies themselves with the teacher's will, children before and after puberty live in the teacher's inner pictures, and adolescents formulate their wakening judgements relying upon the understanding of their teacher. These all require personal encounters and living relationships between human beings. Digital tools demolish and extinguish the space filled with attention by their nature. Waldorf pedagogy examines a child's physical, emotional, social and intellectual development when introducing activities and topics related to modern technology. Thinking about media and educating media is preceded by considering personal developmental perspectives. When using modern technology, movement is typically reduced to the minimal and the eyes are fixed. This form of experience leads to a false stimulus and other negative effects such as hyper-sensitivity of the sensory organs, the danger of addiction, nature deficit disorder, weakening ability to control impulses and damaging reflexive thinking (Bailey, Bailenson, Obradović, \& Aguiar, 2019; Hu, Johnson, Teo, \& Wu, 2020). According to Waldorf pedagogy infants only need to explore and conquer their real environment with their sensory organs, through movement and free play. Children need to create a healthy image of the "I" and feel other people's needs in real life relationships to be able to tackle the ethical, cultural and social questions arising when using modern technology. In Waldorf pedagogy digital media is therefore only introduced during puberty (Hübner, 2015).

Accordingly, Hungarian Waldorf Steiner educational institutions either strictly limit or completely prohibit the use of digital tools in their pedagogical practice. Nevertheless, high school teachers without a Waldorf-teacher certificate, or progressive high school teachers with a Waldorf-teacher certification, have been exploring the possible use of ICT in the Waldorf classroom. The theoretical and empirical research of Waldorf pedagogy and ICT poses a continuous challenge in Waldorf teacher-training.

\section{Conclusion}

The findings show that the institutional use of information and communication technologies contradicts the basis, tasks and spirit of Waldorf pedagogy entirely. Rudolf Steiner often emphasised that the educator has to be standing in their time, in other words, their deeds cannot be alien to their present-day life and culture. According to research studies, one of the reasons for the rapid growth of Waldorf schools in the last 100 years is the flexibility of the pedagogy, according to research studies. If we look at the epistemology and anthroposophical anthropology of Waldorf pedagogy, we can see that the autonomy of a Waldorf teacher is not limitless, and so a continuous practical and theoretical task of the Waldorf movement and Waldorf teachers is to establish and uphold a coherence between the practices of every Waldorf institution and Waldorf pedagogy (Goldshmidt, 2017), rather than to transmit the doctrines of anthroposophy to the learners (Pearce, 2019). If Waldorf schools wish to define 


\section{Acta Educationis Generalis \\ Volume 12, 2022, Issue 1}

themselves as a high-standard alternative to mainstream education, the weaknesses of management and conceptions pointed out by empirical studies (Randoll \& Peters, 2015, pp. 37-39) must be corrected by enhancing professionalism. Aligning the principles and practices in Waldorf schools is fostered by teachers engaging in artistic and self-development activities. In this respect, it is worth pointing out that the personal or institutional use of information technology entirely contradicts the basis, tasks and spirit of Waldorf pedagogy, but this does not exclude thinking about it. On the contrary, it rather urges its exploration: a more and more crucial task for human beings is to embed technology into the world through the intellect.

\section{References}

Bailey, J. O., Bailenson, J. N., Obradović, J., \& Aguiar, N. R. (2019). Virtual reality's effect on children's inhibitory control, social compliance, and sharing. Journal of Applied Developmental Psychology, 64, 101052. https://doi.org/10.1016/j.appdev.2019.101052

Boulding, K. E. (1956). General Systems Theory - The Skeleton of Science. Management Science, 2(3), 197-208. https://doi.org/10.1287/mnsc.2.3.197

Dahlin, B. (2009). On the path towards thinking: Learning from Martin Heidegger and Rudolf Steiner. Studies in Philosophy and Education, 28(6), 537-554. https://doi.org/10.1007/ s11217-009-9147-1

Dávila, J. F., Casabayó, M., \& Rayburn, S. W. (2018). Religious or secular? School type matters as a moderator between media exposure and children's materialism. International Journal of Consumer Studies, 42(6), 779-791. https://doi.org/10.1111/ijcs.12484

Dilthey, W. (1969). The essence of philosophy. New York: AMS Press.

Durkheim, É. (1982). The rules of sociological method. New York: Free Press.

Frierson, P. R. (2014). Maria Montessori's epistemology. British Journal for the History of Philosophy, 22(4), 767-791. https://doi.org/10.1080/09608788.2014.960794

Goldshmidt, G. (2017). Waldorf education as spiritual education. Religion \& Education, 44(3), 346-363. https://doi.org/10.1080/15507394.2017.1294400

Hauschka, R. (2002a). Nature of Substance - Spirit and Matter. Rudolf Steiner Press.

Hauschka, R. (2002b). Nutrition. Forest Row: Sophia Books.

Hu, B. Y., Johnson, G. K., Teo, T., \& Wu, Z. (2020). Relationship between screen time and Chinese children's cognitive and social development. Journal of Research in Childhood Education, 34(2), 183-207. https://doi.org/10.1080/02568543.2019.1702600

Husserl, E. (1981). Husserl: Shorter Works. Notre Dame: University of Notre Dame Press.

Hübner, E. (2015). Medien und Pädagogik. Stuttgart: Pädagogische Forschungsstelle beim Bund der Freien Waldorfsch.

Jin Jeong, Y., Suh, B., \& Gweon, G. (2020). Is smartphone addiction different from Internet addiction? Comparison of addiction-risk factors among adolescents. Behaviour \& Information Technology, 39(5), 578-593. https://doi.org/10.1080/0144929X.2019.1604805

Klimov, B. F. (2012). ICT versus traditional approaches to teaching. Procedia - Social and Behavioral Sciences, 47, 196-200. https://doi.org/10.1016/j.sbspro.2012.06.638

Konok, V., Bunford, N., \& Miklósi, Á. (2020). Associations between child mobile use and digital parenting style in Hungarian families. Journal of Children and Media, 14(1), 91-109. https://doi.org/10.1080/17482798.2019.1684332

Kopasz, M., \& Boda, Z. (2018). Educational reform and trust in the education system. Educatio, 27(4), 548-564. https://doi.org/10.1556/2063.27.2018.002 


\section{Acta Educationis Generalis \\ Volume 12, 2022, Issue 1}

Lankshear, C., Peters, M., \& Knobel, M. (2000). Information, knowledge and learning: Some issues facing epistemology and education in a digital age. Journal of the Philosophy of Education, 34(1), 17-39. https://doi.org/10.1111/1467-9752.00153

Leber, S. (2016). Kommentar zu Rudolf Steiners Vorträgen über Allgemeine Menschenkunde als Grundlage der Pädagogik. Stuttgart: Verlag Freies Geistesleben.

Lejon, H. (1997). Historien om den antroposofiska humanismen: Den antroposofiska bildningsidén i idéhistoriskt perspektiv 1880- 1980 (Doctoral thesis). Stockholm: Stockholms universitet.

Livingstone, S. (2012). Critical reflections on the benefits of ICT in education. Oxford Review of Education, 38(1), 9-24. https://doi.org/10.1080/03054985.2011.577938

Lorenzo, M. F., \& Trujillo, C. M. (2018). Cognitive processes, ICT, and education: A critical analysis. Computers in the Schools, 35(3), 186-203. https://doi.org/10.1080/ 07380569.2018 .1491772

Lovejoy, A. O. (2009). The great chain of being: A study of the history of an idea. Somerset: Transaction.

Mansikka, J.-E. (2007). Om naturens förvandlingar: Vetenskap, kunskap och frihet i Rudolf Steiners tidiga tänkande/idéhistoriska perspektiv på Waldorfpedagogiken. Helsingfors: Helsingfors universitet.

Neurath, O. (1936). International picture language. London: K. Paul, Trench, Trubner \& Co., Ltd.

Oberski, I. (2011). Rudolf Steiner's philosophy of freedom as a basis for spiritual education? International Journal of Children's Spirituality, 16(1), 5-17. https://doi.org/10.1080/ 1364436X.2010.540751

Okumoto, Y. (2019). Enlivening thinking and speech in search of spiritual identity: the role of 'speech formation' in Steiner's Waldorf education. International Journal of Children's Spirituality, 24(1), 83-96. https://doi.org/10.1080/1364436X.2019.1619536

Páleš, E. (2009). Seven archangels: Rhythms of inspiration in the history of culture and nature. Bratislava: Sophia.

Park, W., \& Song, J. (2018). Goethe's conception of "Experiment as Mediator" and implications for practical work in school science. Science \& Education, 27(1-2), 39-61. https://doi.org/10.1007/s11191-018-9965-z

Pearce, J. (2019). From Anthroposophy to non-confessional preparation for spirituality? Could common schools learn from spiritual education in Steiner schools? British Journal of Religious Education, 41(3), 299-314. https://doi.org/10.1080/01416200.2017.1361382

Ramirez, M. Y. (2006). L'enseignement en tant qu'art dans le curriculum Waldorf. University Paris, Saint Denis. Retrieved from https://tel.archives-ouvertes.fr/tel-00180883

Randoll, D., \& Peters, J. (2015). Empirical research on Waldorf education. Educar Em Revista, 2(56), 33-47. https://doi.org/10.1590/0104-4060.41416

Sobo, E. J. (2015). Salutogenic education? Movement and whole child health in a Waldorf (Steiner) School. Medical Anthropology Quarterly, 29(2), 137-156. https://doi.org/10.1111/ maq. 12140

Steiner, R. (1996). The foundations of human experience. Hudson: Anthroposophic Press.

Steiner, R. (2013). Harmony of the Creative Word: The Human Being and the Elemental, Animal, Plant and Mineral Kingdoms. Forest Row: Rudolf Steiner Press.

Steiner, R. (2004). A modern art of education. Great Barrington: Anthroposophic Press.

Steiner, R. (1928). Goethe's conception of the world. Whitefish: Kessinger.

Steiner, R. (1961). The mission of the Archangel Michael. New York: Anthroposophic Press.

Steiner, R. (1967). Die Philosophie der Freiheit: Gründzüge einer modernen Weltanschauung. seelische Beobachtungsresultate nach naturwissenschaftlicher Methode. Stuttgart: Freies Geistesleben.

Steiner, R. (1981). Truth and knowledge. Blauvelt: Steinerbooks.

Steiner, R. (1985). The renewal of the social organism. Spring Valley: Anthroposophic Press. 


\section{Acta Educationis Generalis \\ Volume 12, 2022, Issue 1}

Steiner, R. (1995). Intuitive thinking as a spiritual path: Philosophy of freedom. Hudson: Anthroposophic Press.

Steiner, R. (1997). An outline of esoteric science. Hudson: Anthroposophic Press.

Steiner, R. (2000). Geisteswissenschaftliche Impulse zur Entwicklung der Physik. Dornach: Rudolf Steiner Verlag.

Steiner, R. (2003). Cosmology, religion and philosophy. Belle Fourche: Kessinger.

Steiner, R. (2006). Vom Leben des Menschen und der Erde. Über das Wesen des Christentums. Dornach: Rudolf Steiner Verlag.

Steiner, R. (2011). Knowledge of the higher worlds. Forest Row: Rudolf Steiner Press.

Yamada, T., Moshier, S. J., \& Otto, M. W. (2016). No site unseen: Predicting the failure to control problematic Internet use among young adults. Cognitive Behaviour Therapy, 45(6), 496-500. https://doi.org/10.1080/16506073.2016.1205657

Zsolnai, A. (2017). The impact of electronic media on social behaviour and social relationships in adolescence. Educatio, 26(2), 246-256. https://doi.org/10.1556/2063.26.2017.2.7 